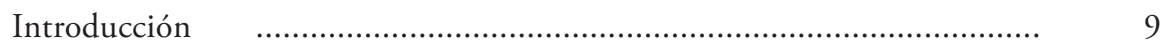

Criterios de edición ................................................................................ 27

Modo de empleo …............................................................................ 27

Agradecimientos …............................................................................. 28

\title{
Correspondencia (1927-1950)
}

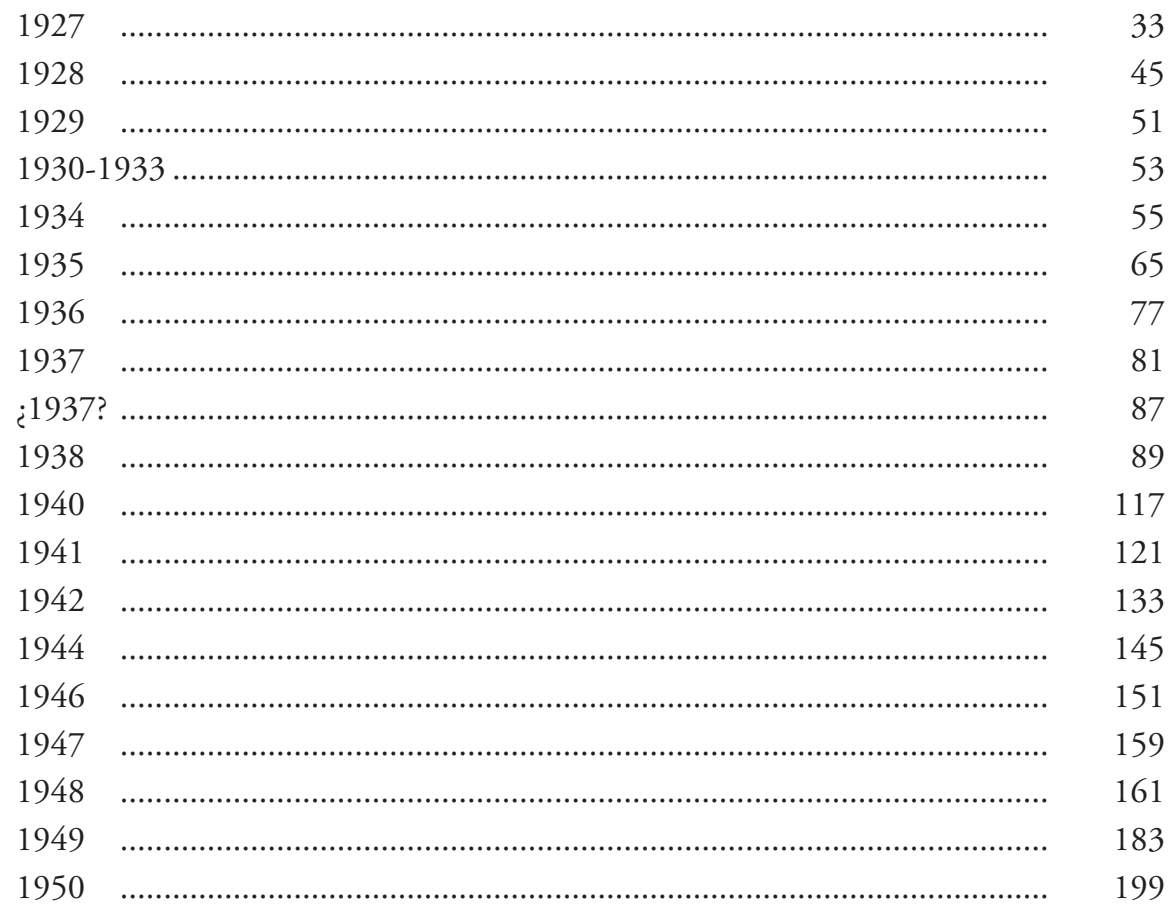


Apéndice 1(1951-1969)

211

Apéndice 2

Índice de cartas y postales....................................................................... 239

Procedencia de los materiales.................................................................... 241

Bibliografía........................................................................................... 243 
